\begin{tabular}{lll}
\hline \hline VOLUME 1 & Number 1 & Page $31-36$ \\
\hline
\end{tabular}

\title{
Campur Kode Bahasa Indonesia Dan Bahasa Kutai Dialeg Tenggarong Kota Di Kantor Desa Separi Kabupaten Kutai Kartanegara
}

\author{
Muhammad Anwar, Syaiful Arifin, Asnan Hefni \\ Universitas Mulawarman \\ Universitas Mulawarman \\ Universitas Mulawarman \\ Email: anwar.muh231@gmail.com
}

\begin{abstract}
This research was conducted to develop the Kutai language in the Tenggarong Kota dialect and at the same time as a contribution of knowledge related to the mixing of the codes for the Kutai language in the Tenggarong Dialect. Thus, local languages can continue to be preserved so that speakers of regional languages can use regional languages according to their place and situation. The research objective was to determine the code mixing event that occurred in the Separi Village Office, Kutai Kartanegara Regency and to describe the insertion of language elements that was more dominant in the code mixing event. The method used in this qualitative research is observation, the observation method with basic techniques, namely tapping techniques and note taking techniques. The results showed that code mixing occurred in the Separi Village Office, Kutai Kartanegara Regency, between Indonesian and Kutai languages. The code mixing that occurs is indicated by the insertion of linguistic elements in the form of words, phrases and clauses. The most dominant insertion of linguistic elements in the code mixing process at the Separi Village Office, Kutai Kartanegara Regency, is the insertion of linguistic elements in the form of phrases.
\end{abstract}

Keywords : mixed codes, indonesian, kutai language, dialeg tenggarong kota

\section{Pendahuluan}

Di Indonesia, komunitas pemakaian bahasa sangatlah banyak dan beraneka ragam karena semua terdiri dari suku-suku, kebangsaan, dan kebudayaan yang beraneka ragam. bahasa Indonesia digunakan masyarakat untuk berkomunikasi dengan penutur etnik lain seperti di pasar, di kantor, di sekolah, di tempat-tempat lainnya bahasa daerah dipergunakan untuk berkomunikasi dengan penutur sesama etnik dan walaupun beraneka ragam suku dan bahasa, namun sebagai bangsa Indonesia kita semua tetap bersatu dalam bahasa kesatuan yaitu bahasa Indonesia.

Menurut Chaer dan Agustina (2010: 11) Bahasa merupakan sebuah sistem, maksudnya bahasa tercipta dari kumpulan komponen yang berpola tetap dan dapat dikaidahkan. Mengingat pentingnya bahasa dalam menjalankan segala aktivitas sehari-hari, tentu semua selalu terlibat dalam komunikasi, baik bertindak sebagai komunikator (pembicara) maupun sebagai komunikan (penyimak). Hakikat Bahasa sebagai alat interaksi sosial dan suatu sistem yang dimiliki manusia untuk berkomunikasi dalam menyampaikan suatu pembicaraan. Peristiwa komunikasi yang berlangsung tersebut dapat dijadikan tempat atau media untuk mengungkapkan ide, isi pikiran, gagasan, dan sebagainya.

Adapun pengertian bahasa Kutai menurut Darma (2013: 15) Bahasa Kutai merupakan bahasa Melayu yang hidup dan berkembang sejalan dengan perkembangan Suku Kutai. Suku Kutai 
adalah suku yang mendiami alur sepanjang sungai Mahakam dan populasinya terbesar di wilayah bekas Kabupaten terdahulu. Bahasa Kutai dipergunakan dalam kehidupan seharihari oleh suku Kutai dan Bahasa Kutai umumnya hidup dan berkembang dalam bentuk penuturan (percakapan), serta sastra dalam bentuk puisi.

Campur kode biasanya terjadi dalam formal atau informal, namun dapat terjadi dalam situasi formal khususnya bahasa lisan. Hal ini terjadi di Kantor Desa Separi Kabupaten Kutai Kartanegara, saat melakukan interaksi pasti ada yang melakukan campur kode bahasa Indonesia dan bahasa Kutai baik dalam situasi formal maupun informal antara sesama pegawai dan para tamu. Berdasarkan kasus tersebut, penulis terpanggil untuk melalukan penelitian lebih lanjut karena penelitian mengenai campur kode bahasa Indonesia dan bahasa Kutai dialeg Tenggarong kota di Kantor Desa Separi Kecamatan Tenggarong Seberang Kabupaten Kutai Kartanegara belum pernah ada.

\section{Tujuan Penelitian}

Dari rumusan masalah di atas, peneliti merumuskan tujuan pembahasan dalam penelitian ini. Adapun tujuan pembahasan dalam penelitian ini antara lain:

1. Mendeskripsikan peristiwa campur kode yang terjadi di Kantor Desa Separi Kabupaten Kutai Kartanegara.

2. Mendeskripsikan penyisipan unsur kebahasaan yang lebih dominan terjadi dalam peristiwa campur kode di Kantor Desa Separi Kabupaten Kutai Kartanegara.

\section{Tinjauan Pustaka}

\section{A. Peristiwa Kebahasaan}

Menurut Chaer dan Agustina (2010: 11), bahasa merupakan sebuah sistem, maksudnya bahasa tercipta dari kumpulan komponen yang berpola tetap dan dapat dikaidahkan, menurut Carrol (dalam Oka, 1994: 2), menyatakan bahasa adalah sistem bunyi dan urutan bunyi vocal yang terstruktur yang digunakan, atau dapat digunakan, dalam komunikasi interpersonal oleh sekelompok manusia dan secara lengkap digunakan untuk mengungkapkan sesuatu, peristiwa, dan proses yang terdapat di sekitar manusia, menurut Nababan (1993: 46), bahasa ialah suatu sistem perisyaratan (semiotik) yang terdiri dari unsur-unsur isyarat dan hubungan antara unsur-unsur itu. Dari beberapa pendapat para ahli di atas, dapat disimpulkan bahwa bahasa merupakan suatu sistem yang terdiri dari unsur-unsur atau bunyi dalam komunikasi.

\section{B. Perbedaan Alih Kode dan Campur Kode}

Menurut Chaer dan Agustina (2010: 114), kesamaan yang ada antara alih kode dan campur kode adalah digunakannya dua bahasa atau lebih, atau dua varian dari sebuah bahasa dalam satu masyarakat tutur. Namun kedua aspek ini juga ada perbedaannya yakni di dalam alih kode setiap penyisipan bahasa atau ragam yang digunakan itu masih memiliki otonomi atau aturan masing-masing, dilakukan dengan sadar dan ada unsur kesengajaan yang disebabkan oleh hal tertentu dan di lingkungan masyarakat yang beragam akan sering dijumpai beberapa orang yang menggantikan bahasa atau ragam bahasanya dalam peristiwa tutur. Hal ini tergantung pada keadaan atau keperluan berbahasa itu sendiri. Kejadian yang seperti itu yang disebut alih kode.

Alih kode biasanya digunakan secara sengaja atau secara sadar. Hal ini dikarenakan alih kode sebagaian besar digunakan untuk menghormati lawan bicara dan ingin membuat percakapan tersebut menjadi lebih mendalam dan berbeda dengan halnya campur kode, sebagian besar peristiwa campur kode dilakukan seseorang secara tidak sengaja atau tidak disadari. Hal ini dikarenakan sikap multibahasa orang tersebut yang membuat ia mencampurkan beberapa frasa bahasa asing ke bahasa asli.

\section{Pengertian Campur Kode}

Dalam suatu peristiwa campur kode bisa terjadi apabila penutur bahasa, misalnya bahasa Indonesia memasukan unsur-unsur bahasa daerahnya ke dalam pembicaraan bahasa Indonesia. Dengan kata lain, seseorang yang berbicara dengan kode utama bahasa Indonesia yang memiliki fungsi keotonomiannya, sedangkan kode bahasa daerah yang terlibat dalam kode utama merupakan serpihan-serpihan saja tanpa fungsi atau keotonomian sebagai sebuah kode.

Menurut Thelender (dalam Aslinda dan Syafyahya, 2007: 87), jika dalam suatu peristiwa tutur klausa-klausa dan frase-frase yang digunakan terdiri dari klausa dan frase campuran dan masing-masing klausa atau frase itu tidak lagi mendukung fungsi sendiri-sendiri, maka peristiwa peristiwa yang terjadi adalah campur kode. Dengan kata lain, jika seseorang 
menggunakan suatu kata/frase dari satu bahasa, orang tersebut telah melakukan campur kode.

\section{Penyisipan unsur kebahasaan dalam Campur Kode}

Dalam peristiwa campur kode terdapat beberapa penyisipan unsur kebahasaan yang terjadi di dalamnya sehingga bisa dikatakan bahwa peristiwa tersebut merupakan sebuah campur kode. Menurut Chaer dan Agustina (2010: 116), campur kode itu dapat berupa pencampuran serpihan kata, frase, dan klausa suatu Bahasa di dalam Bahasa lain yang digunakan. Adapun penjelasannya sebagai berikut:

\section{Kata}

Bidang lingustik yang mempelajari struktur kata adalah morfologi. Dalam tataran morfologi, kata merupakan satuan terbesar (satuan terkecilnya adalah morfem), tetapi dalam tataran sintaksis kata merupakan satuan terkecil.

Menurut Chaer (2014: 162), kata adalah satuan bahasa yang memiliki satu pengertian atau kata adalah deretan huruf yang diapit oleh dua buah spasi, dan mempunyai satu arti.

\section{- Saya ndak bertemu dengan teman}

\section{Frase}

Menurut Cook (dalam Tarigan 2015: 96), frase adalah satuan linguistik yang secara potensial merupakan gabungan dua kata atau lebih, yang tidak mempunyai ciri-ciri klausa. Ciri-ciri klausa yang paling utama adalah tidak memiliki intonasi akhir dan memiliki sebuah predikat.

Dari definisi di atas dapat disimpulkan bahwa frase merupakan gabungan dua kata atau lebih yang bersifat nonpredikatif. Adapun contoh penyisipan campur kode berupa frase sebagai berikut:

\section{Klausa}

$$
\text { - Sabar,aku masih bebaju }
$$

Menurut Chaer (2014: 231), klausa adalah satuan sintaksis berupa runtutan kata-kata berkontruksi predikatif. Artinya, di dalam konstruksi itu ada komponen berupa kata atau frase yang berfungsi sebagai predikat dan yang lain berfungsi sebagai subjek, sebagai objek, dan sebagai keterangan.

Menurut Ramlan (2005: 79), klausa adalah sebagai satuan gramatik yang terdiri dari S P baik disertai (O), (PEL), dan (KET) ataupun tidak. Tanda kurung menandakan bahwa apa yang terletak dalam kurung itu bersifat manasuka, boleh ada, boleh tidak.

Dari beberapa pendapat ahli di atas, dapat dsimpulkan bahwa klausa adalah gabugan dari beberapa kata yang sekurangkurangnya terdiri atas subjek dan predikat, boleh dilengkapi (objek), (pelengkap), dan (keterangan). Adapun contoh penyisipan campur kode berupa klausa sebagai berikut:

○ Kakak ndak mandi dulu

\section{Metode}

Jenis penelitian yang peneliti lakukan adalah penelitian kualitatif, Penelitian kualitatif adalah tradisi tertentu dalam ilmu pengetahuan sosial secara fundamental bergantung pada pengamatan manusia dalam kawasan sendiri dan berhubungan dengan masyarakat tersebut melalui bahasanya, serta peristilahan. Sumber data untuk penelitian ini didapatkan dari Informan atau penutur yang sedang melakukan interaksi campur kode di Kantor Desa Separi Kabupaten Kutai Kartanegara.

Adapun teknik pengumpulan data dalam penelitian ini adalah observasi, metode simak, teknik catat. Teknik analisis data dengan menggunakan pola tindak tutur SPEAKING oleh Dell Hymes yang dikutip dari Chaer dan Agustina (2010: 48).

\section{Hasil dan Pembahasan}

Kantor desa Separi merupakan salah satu kantor desa yang berada di desa Separi Kecamatan Tenggarong Seberang Kabupaten Kutai Kartanegara. Kantor desa separi ini terletak tidak jauh dari bantaran sungai Mahakam, dan kantor desa Separi ini memiliki 24 pegawai dan dipimpin oleh kepala desa yang bernama bapak Sugianto, SH.

Pencampuran Bahasa yang dilakukan oleh penutur dan lawan tutur di Kantor Desa Separi Kecamatan Tenggarong Seberang Kabupaten Kutai Kartanegara mengakibatkan terjadinya sebuah peristiwa kebahasaan yaitu campur kode. Campur kode merupakan pemakaian dua Bahasa atau lebih dengan cara memasukan unsur Bahasa satu kebahasa lainnya. Penggunaan campur kode dapat berwujud kata, frase, dan klausa.

Dari hasil penelitian yang dilakukan penulis di Kantor Desa Separi Kecamatan Tenggarong Seberang Kabupaten Kutai Kartanegara menunjukan bahwa dari 15 peristiwa tutur yang dilakukan telah terjadi sebuah campur kode antara bahasa Indonesia dan bahasa Kutai dengan memasukan penyisipan unsur kebahasaan dalam suatu tuturan. 
Adapun penyisipan unsur kebahasaan tersebut sebagai berikut.

\begin{tabular}{|c|c|c|c|}
\hline \multicolumn{4}{|l|}{ A. Penyisipan } \\
\hline \multicolumn{4}{|c|}{$\begin{array}{l}\text { Berdasarkan analisis data, dihasilkan } 17 \\
\text { lah kata yang menyisip dalam peristiwa } \\
\text { tur yang berasal dari percakapan }(1),(2) \text {, } \\
),(4),(6),(10),(11),(12),(14),(15) \text {. Unsur } \\
\text { rsebut meliputi. } \\
\text { Tabel 1. Bahasa Kutai ke Dalam Bahasa } \\
\text { Indonesia }\end{array}$} \\
\hline Percakapan & $\begin{array}{c}\text { Kata } \\
\text { bahasa } \\
\text { kutai }\end{array}$ & Arti & $\begin{array}{l}\text { Tulisan } \\
\text { fonetis }\end{array}$ \\
\hline $1,3,4$ & Ndak & Mau & [nda?] \\
\hline 2 & Jua & Juga & [jua] \\
\hline 3 & Kemak & Binggung & [kəma?] \\
\hline 4 & Mpai & Besok & [mpaI] \\
\hline 4 & Pegi & Pergi & [pəgi] \\
\hline 6 & Etam & Kita & [Etam] \\
\hline
\end{tabular}

Tabel 2. Bahasa Indonesia Menyisip ke Dalam Bahasa Kutai

\begin{tabular}{|c|c|c|c|}
\hline Percakapan & $\begin{array}{c}\text { Kata } \\
\text { Bahasa } \\
\text { Indonesia }\end{array}$ & Arti & $\begin{array}{l}\text { Tulisan } \\
\text { Fonetis }\end{array}$ \\
\hline 10 , & Sudah & & [sudah] \\
\hline 10 & Curhat & & [curhat] \\
\hline 10,12 & $\mathrm{Aku}$ & & [aku] \\
\hline 11 & $\begin{array}{c}\text { Ganti- } \\
\text { ganti }\end{array}$ & & [ganti-ganti] \\
\hline 11 & Baru & & [baru] \\
\hline 11 & Langsung & & [laysun] \\
\hline 12 & Berarti & & [bərarti] \\
\hline 14,15 & Ada & & [ada] \\
\hline 14 & Sederhana & & [səderhana] \\
\hline 15 & Masih & & [masIh] \\
\hline 15 & Tadi & & [tadi] \\
\hline
\end{tabular}

B. Penyisipan Unsur Kebahasaan Berupa Frase

Berdasarkan analisis data, dihasilkan 22 buah frase yang menyisip dalam peristiwa tutur yang berasal dari percakapan (4), (5), (6), (7), (8), (9), (10), (11), (12), (13), (14), (15). Unsur tersebut meliputi.

Tabel 3. Bahasa Kutai Menyisip ke Dalam Bahasa Indonesia

\begin{tabular}{|c|c|c|c|}
\hline Percakapan & $\begin{array}{c}\text { Kata } \\
\text { bahasa } \\
\text { kutai }\end{array}$ & Arti & $\begin{array}{l}\text { Tulisan } \\
\text { fonetis }\end{array}$ \\
\hline 4 & Ndik da & Tidak ada & $\begin{array}{l}\text { [ndI? } \\
\text { ada] }\end{array}$ \\
\hline 4 & $\begin{array}{l}\text { Ndik da } \\
\text { bilanya }\end{array}$ & $\begin{array}{c}\text { Tidak ada } \\
\text { nanti }\end{array}$ & $\begin{array}{c}\text { [ndI? da } \\
\text { bilañ] }\end{array}$ \\
\hline 4 & $\begin{array}{c}\text { Ndik da } \\
\text { yang } \\
\text { kawa }\end{array}$ & $\begin{array}{l}\text { Tidak ada } \\
\text { yang bisa }\end{array}$ & $\begin{array}{c}\text { [ndI? } \\
\text { ada yay } \\
\text { kawa] }\end{array}$ \\
\hline
\end{tabular}

\begin{tabular}{|c|c|c|c|}
\hline 4 & $\begin{array}{l}\text { Mana } \\
\text { kawa }\end{array}$ & Mana bisa & $\begin{array}{l}\text { [mana } \\
\text { kawa] }\end{array}$ \\
\hline 5,6 & Tegak tu & $\begin{array}{c}\text { Kayak } \\
\text { gitu }\end{array}$ & $\begin{array}{c}\text { [təga? } \\
\text { Tu] }\end{array}$ \\
\hline 7 & Bunyinya & Bilangnya & [buñiña] \\
\hline 8 & Sida & Mereka & [sida \\
\hline & tegaknya & kayaknya & təga?ñ] \\
\hline 9 & $\begin{array}{l}\text { Ndik } \\
\text { dapat }\end{array}$ & Tidak bisa & $\begin{array}{l}\text { [ndI? } \\
\text { dapat] }\end{array}$ \\
\hline
\end{tabular}

Tabel 4. Bahasa Indonesia Menyisip ke Dalam Bahasa Kutai

\begin{tabular}{|c|c|c|c|}
\hline Percakapan & $\begin{array}{c}\text { Kata } \\
\text { bahasa } \\
\text { Indonesia }\end{array}$ & Arti & $\begin{array}{l}\text { Tulisan } \\
\text { fonetis }\end{array}$ \\
\hline 10 & Hari sabtu & & $\begin{array}{l}\text { [hari } \\
\text { sabtu] }\end{array}$ \\
\hline 11 & Makanya & & [makaña] \\
\hline 11 & $\begin{array}{l}\text { Cewek } \\
\text { ganti-ganti }\end{array}$ & & $\begin{array}{c}{[\mathrm{cEwE} ?} \\
\text { ganti- } \\
\text { ganti] }\end{array}$ \\
\hline 11 & $\begin{array}{c}\text { Kerja gajian } \\
\text { pertama }\end{array}$ & & $\begin{array}{c}\text { [kərja } \\
\text { gajian } \\
\text { pertama] }\end{array}$ \\
\hline 11 & $\begin{array}{c}\text { Tau } \\
\text { kubawakan }\end{array}$ & & $\begin{array}{c}{[\text { tau }} \\
\text { kubawaka } \\
\text { n] }\end{array}$ \\
\hline 12 & $\begin{array}{l}\text { Ke saya } \\
\text { fotonya } \\
\text { beda }\end{array}$ & & $\begin{array}{c}\text { [kə saya } \\
\text { fotoñ } \\
\text { bEda] }\end{array}$ \\
\hline 12 & Misalkan & & $\begin{array}{c}\text { [misalkan } \\
\text { ] }\end{array}$ \\
\hline 12 & $\begin{array}{c}\text { Mana } \\
\text { batasnya }\end{array}$ & & $\begin{array}{c}\text { [mana } \\
\text { batasñ] }\end{array}$ \\
\hline 13 & $\begin{array}{l}\text { Harus } \\
\text { dengan foto- } \\
\text { fotonya kan }\end{array}$ & & $\begin{array}{c}\text { [harus } \\
\text { dəyan } \\
\text { foto-fotoñ } \\
\text { kan] }\end{array}$ \\
\hline 13 & Bukan saya & & $\begin{array}{c}\text { [bukan } \\
\text { saya] }\end{array}$ \\
\hline 14 & $\begin{array}{c}\text { Penting } \\
\text { lokasi }\end{array}$ & & $\begin{array}{l}\text { [pontin } \\
\text { lokasi] }\end{array}$ \\
\hline 14 & Sekarang ini & & $\begin{array}{l}\text { [səkaray } \\
\text { ini] }\end{array}$ \\
\hline 14 & Mantapnya & & $\underset{]}{\text { [mantapñ }}$ \\
\hline 15 & Yaudah ya & & $\begin{array}{c}\text { [yaudah } \\
\text { ya] }\end{array}$ \\
\hline
\end{tabular}

\section{Penyisipan Unsur Berupa Klausa}

Berdasarkan analisis data, dihasilkan 7 buah klausa yang menyisip dalam peristiwa tutur yang berasal dari percakapan (10), (11), (12), (13), (15). Unsur tersebut meliputi.

Tabel 5. Bahasa Indonesia Menyisip ke Dalam Bahasa Kutai

\begin{tabular}{cccc}
\hline Pecakapan & $\begin{array}{c}\text { Kata bahasa } \\
\text { Indonesia }\end{array}$ & Arti & $\begin{array}{c}\text { Tulisan } \\
\text { fonetis }\end{array}$ \\
\hline 10 & $\begin{array}{c}\text { Disuruhnya } \\
\text { balik lagi, yah }\end{array}$ & [disuruhñ \\
ball? Lagi,
\end{tabular}




\begin{tabular}{|c|c|c|}
\hline & kami balik lagi & yah kami \\
\hline 11 & $\begin{array}{c}\text { Ndak mungkin, } \\
\text { tu ada proses } \\
\text { feri }\end{array}$ & $\begin{array}{l}\text { [nda? } \\
\text { Muykin, tu } \\
\text { ada proses } \\
\text { feri] }\end{array}$ \\
\hline 12 & $\begin{array}{l}\text { Dengan yang } \\
\text { itu tadi ya lain } \\
\text { titiknya }\end{array}$ & $\begin{array}{l}\text { [dənan yan } \\
\text { itu tadi ya } \\
\text { lain titI?ñ] }\end{array}$ \\
\hline 13 & $\begin{array}{l}\text { Beda lain salah } \\
\text { saya }\end{array}$ & $\begin{array}{l}\text { [bEda, lain } \\
\text { salah saya] }\end{array}$ \\
\hline 15 & $\begin{array}{l}\text { Biar ditemani } \\
\text { agus aja }\end{array}$ & $\begin{array}{c}\text { [biar } \\
\text { ditəmani } \\
\text { agus aja] }\end{array}$ \\
\hline 15 & $\begin{array}{c}\text { Saya potonya } \\
\text { dengan om } \\
\text { agus buk, ada } \\
\text { foto dengan om } \\
\text { agus }\end{array}$ & $\begin{array}{l}\text { [saya potoñ } \\
\text { dəyan om } \\
\text { agus bu?, } \\
\text { ada foto } \\
\text { dəyan om } \\
\text { agus }\end{array}$ \\
\hline 15 & $\begin{array}{c}\text { Yang penting } \\
\text { sudah pas aja } \\
\text { kan lokasinya } \\
\text { ya kan }\end{array}$ & $\begin{array}{c}\text { [yang } \\
\text { pəntin } \\
\text { sudah pas } \\
\text { aja kan } \\
\text { lokasiñ ya } \\
\text { kan] }\end{array}$ \\
\hline
\end{tabular}

Berdasarkan hasil penelitian yang dilakukan penulis, ditemukan penyisipan unsur dalam campur kode berupa kata sebanyak 17 buah, frase sebanyak 22, dan klausa sebanyak 7 buah. Jadi penyisipan unsur kebahasaan yang paling dominan dalam peristiwa campur kode di Kantor Desa Separi adalah unsur frase.

Dalam rangka bekerja sama dengan sesamanya, manusia memerlukan bahasa yang digunakan untuk slaing berkomunikasi. Keinginan atau maksud tidak tersampaikan dengan baik tanpa adanya bahasa. Oleh karena itu peran bahasa sangat penting di dalam kehidupan sehari-hari.

Dalam kehidupan berbangsa, bernegara, dan bermasyarakat manusia tidak lepas dari kenyataan bahwa suatu bangsa adalah tempat hidup dan berkembang beragamnya suku yang masing-masing suku tersebut memiliki bhasa daerahnya masing-masing. Kita juga dapat melihat bahwa beragamnya masyarakat menyebabkan munculnya beragam bahasa.

Dari uraian yang telah diperoleh pada hasill penelitian, bahwa peristiwa tutur di Kantor Desa Separi Kabupaten Kutai Kartanegara benar mengalami campur kode. Campur kode dalam tuturan terjadi dengan menyisipkan bahasa baik berupa kata, frase, atau klausa. Penyisipan unsur tersebut terjadi baik dari bahasa Indonesia menyisip ke dalam bahaha kutai ataupun dari bahasa kutai menyisip ke dalam bahasa indoensia. Dapat dilihat pada contoh berikut ini:

1. Penyisipan unsur kebahasaan berupa kata DATA 1

Saya : mau bertemu kepala desanya!

Kepala desa : kepala desanya?

Kepala desa : buk, ndak ketemu kepala desanya

Tamu : ini hak

Saya : ooooohhh

Kepala desa : hahahahhahaha

\section{KESIMPULAN DAN SARAN}

Berdasarkan permasalahan dan tujuan yang telah dirumuskan pada bab-bab sebelumnya, dalam penelitian ini dengan penyajian data, analisis data dan pembahasan, maka dapat disimpulkan sebagai berikut:

1. Campur Kode bahasa Indonesia dan bahasa Kutai dialek Tenggarong Kota di Kantor Desa Separi Kabupaten Kutai Kartanegara jika dilihat memiliki arti tersirat, maka akan memiliki makna yang banyak diantaranya adalah makna dari segi agama, segi watak, dan dari segi sosial. Campur kode terjadi dengan berbagai maksud, seperti untuk memudahkan dalam berkomunikasi, menciptakan suasana akrab, santai, dan sekedar guyonan.

2. Campur kode terjadi dengan adanya penyisipan unsur kebahasaan yang menyisip ke dalam tuturan adalah sebgai berikut:

a. Bentuk kata

Penyisipan unsur kebahasaan berupa kata terjadi dari bahasa Indonesia ke dalam bahasa kutai maupun sebaliknya. Unsur yang menyisip dari bahasa kutai dalam tuturan bahasa Indonesia, yaitu: Ndak 'mau', Jua 'juga', Kemak 'binggung', Mpai 'besok', Pegi 'pergi', Etam 'kita'. Unsur yang menyisip dari bahasa Indonesia dalam tuturan bahasa Kutai, yaitu: sudah, curhat, aku, ganti-ganti, baru, langsung, berarti, ada, sederhana, masih, tadi.

b. Bentuk frase

Penyisipan unsur kebahasaan berupa frase terjadi dari bahasa Indonesia ke dalam bahasa Kutai maupun sebaliknya. Unsur yang menyisip dari bahasa Kutai ke dalam tuturan bahasa Indonesia,yaitu: ndik da 'tidak ada', ndik da bilanya 'tidak ada nanti', ndik da yang kawa 'tidak ada yang bisa', mana kawa 'mana bisa', tegak tu 
'kayak gitu', bunyinya 'bilangnya', sida tegaknya 'mereka kayaknya', ndik dapat 'tidak bisa'. Unsur yang menyisip dari bahasa Indonesia ke dalam tuturan bahasa Kutai, yaitu: hari sabtu, makanya, cewek ganti-ganti, kerja gajian pertama, tau kubawakan, ke saya fotonya beda, misalkan, mana batasnya, harus dengan foto-fotonya kan, bukan saya, penting lokasi, sekarang ini, mantapnya, yaudah ya.

c. Bentuk klausa

Penyisipan unsur kebahasaan berupa klausa terjadi dari bahasa Indonesia ke dalam bahsa Kutai maupun sebaliknya. Usnur yang menyisip dari bahasa Indonesia ke dalam tuturan bahasa Kutai, yaitu: "Disuruhnya balik lagi, yah kami balik lagi", "Ndak mungkin, tu ada proses feri", "Dengan yang itu tadi ya lain titiknya", "Beda ,lain salah saya", "Biar ditemani agus aja", "Saya potonya dengan om agus buk, ada foto dengan om agus", "Yang penting sudah pas aja kan lokasinya ya kan".

B. Saran

1. Diharapkan agar penelitian ini dapat dijadikan salah satu informasi dalam penelitian yang berhubungan dengan campur kode.

2. Perlu adanya penelitian lanjutan yang lebih luas dan lebih lengkap mengenai penyisipan unsur dalam campur kode.

3. Penulis sangat mengharapkan perhatian ahli-ahli bahasa untuk memberi perhatian terhadap peristiwaperistiwa bahasa yang ada di dalam masyarakat bilingual.

4. Agar bahasa Kutai dialek Tenggorong Kota bisa digunakan di tempat dan situasi yang sebagai mana mestiya .

\section{REFERENSI}

Aslinda, dan Leni Syafyahya. (2014). Pengantar Sosiolingustik. Bandung: PT. Refika Aditama.

Chaer, Abdul, dan Leonie Agustina. (2010). Sosiolinguistik Perkenalan Awal. Jakarta: PT. Rineka Cipta.

Chaer, Abdul. (2014). Linguistik Umum. Jakarta: PT. Rineka Cipta.

Darma, M. Erwin, el.al. (2013). Kamus Bahasa Kutai - Bahasa Indonesia. Samarinda: Kantor Bahasa Provinsi Kalimantan Timur Badan Pengembangan Dan Pembinaan Bahasa Kementrian Pendidikan Dan Kebudayaan.
Djajasudarma, T. Fatimah. (1993). Metode Linguistik Ancangan Metode Penelitian Dan Kajian. Bandung: Refika Aditama.

Mahsun. (2017). Metode Penelitian Bahasa: Tahapan, Strategi, Metode, Dan Tekniknya. Dep ok: Rajawali Pers.

Nababan, P.W.J. (1993). Sosiolinguistik Suatu Pengantar. Jakarta: PT. Gramedia Pustaka Utama.

Oka, I.G.N, et.al. (1994). Lingustik Umum. Jakarta.

Pateda, Mansoer. 1988. Linguistik (Sebuah Pengantar). Bandung: Angkasa.

Ramlan, M. (2005). Sintaksis. Yogyakarta: CV. Karyono.

Suandi, I Nenggah. (2014). Sosiolinguistik. Yogyakarta: Graha Ilmu.

Sudaryanto. (2015). Metode Dan Aneka Analisis Bahasa. Yogyakarta: Sanata Dharma University Pres.

Sugiono. (2016). Metode Penelitian Kuantitatif, Kualitatif, Dan $R \& D$. Bandung: Alfabeta. (2015). Memahami Penelitian Kualitatif. Bandung: Alfabeta.

Tarigan, Henry. Guntur. (2015). Pengajaran Sintaksis. Bandung: CV. Angkasa.

Verhaar, J.W.M (1984). Pengantar Linguistik. Gadjah Mada University Pres. 